\title{
The management of public libraries
}

'A clear policy must be formulated defining objectives, priorities and services in relation to the local community needs. The public library has to be organised effectively and professional standards of operation must be maintained.'

(IFLA/UNESCO Public Library Manifesto, 1994)

\subsection{Introduction}

A successful public library is a dynamic organisation working with other institutions and with individuals to provide a range of library and information services to meet the varied and changing needs of the community. To be effective it requires experienced, flexible and well trained managers and staff able to use a range of management techniques. This chapter deals with the key elements of public library management.

\subsection{Management skills}

Management of a public library involves a number of different skills:

- leadership and motivation

- maintaining effective relationships with governing and funding bodies

- planning and policy development

- building and maintaining networks with other organisations

- budget negotiations and management

- management of library resources

- staff management

- planning and development of library systems

- the management of change

- marketing and promotion 
- community liaison and lobbying

- raising funds from alternative funding sources.

\subsubsection{Leadership and motivation}

The library manager has a vital role in advocating the value of public libraries as an integral part of an international, national and local infrastructure. $\mathrm{He} / \mathrm{she}$ must promote public libraries to politicians and key stakeholders at all levels in order to ensure they are aware of the importance of public libraries and to attract adequate funding for their maintenance and development. The library manager must ensure that governing authorities are informed of new developments that may impact on public library services and are also made aware that the library's services are key players in providing access to the delivery of new services.

The library manager is responsible for the motivation of staff and bringing energy, vitality and strength into the library service and its staff. The manager also plays a key role in managing the development of physical facilities and ensuring that the most effective use is made of resources, including information technology, to enable the library service to meet the library and information needs of the community.

\subsubsection{Relationships with governing and funding bodies}

To achieve its goals the public library needs adequate and sustained funding. It is very important that the library manager establishes and maintains a close and positive relationship with the bodies that govern the library service and provide its funding (this is sometimes called advocacy). The library manager as head of the public library service should have direct access to and involvement with the board or committee that is directly responsible for the library service. As well as formal meetings there should be regular informal contacts between the library manager and members of the governing body, and they should be kept well informed about the library service and current and future developments.

\subsubsection{Planning and policy development}

Planning ensures that:

- the library responds to the needs of the community

- the governing body, management and staff understand what the library is trying to achieve 
- community funds are spent in an effective and responsible manner

- continuity of service is maintained regardless of changes of personnel

- the library expands the expectations of the community as new services are developed

- the library is able to respond effectively to change.

The determination of public library goals, short and long term objectives, strategies and performance measurement is necessary to ensure equitable, effective and efficient library service provision with access for all sectors of the community. Strategic and operational plans require formulation, documentation and adoption.

Planning should not take place in isolation but in conjunction with the governing and funding bodies, the library staff and the actual and potential clients served. A strategic plan must be customer-focused and should include the following elements:

- review of achievements

- examination of needs

- vision and mission statements

- identification of priorities and short term goals

- development of strategies for achieving goals

- identification of critical success factors

- budget allocation

- deployment of resources to achieve optimum performance

- measurement and evaluation of input, output and outcome measures for customers

- reassessment of needs and policies.

\subsubsection{Operational planning}

An operational plan is necessary to ensure that the activities of the library service are focused on achieving the priorities and goals identified in the strategic plan. The plan should reflect the following elements:

- a focus on service to customers

- the implementation of the priorities and goals of the strategic plan

- the formation of operational elements of the agreed strategies

- the development of clearly identified goals with manageable and achievable time frames

- the definition of achievable outputs for the level of inputs

- the participation of library staff who carry out the activities 
- the allocation of responsibility to identified staff members for achieving outputs

- a programme for monitoring, evaluating and amending the plan at regular intervals.

By-laws or local legislation, specific policies and procedures may be needed and should be properly formulated, documented and communicated to all those involved. Business and marketing plans, market research, community needs analyses and surveys of actual and potential customers should form part of the management process.

Planning for the future should advocate positive change and flexibility and aim to minimise the impact of transition on services, staff and customers. To achieve effective change, all stakeholders must be involved in the change process.

\subsubsection{Green (environmentally friendly) libraries}

The built environment has a vast impact on the natural environment, human health, and the economy. By adopting green building and operational strategies, public libraries can maximise both economic and environmental performance. Green construction methods can be integrated into buildings at any stage, from design and construction, to renovation and demolition. However, the most significant benefits can be obtained if the design and construction team takes an integrated approach from the earliest stages of a building project.

The World Green Building Council documents nine Green Building Rating Systems on its website < http://www.worldgbc.org/greenbuilding-councils/green-building-rating-tools $>$. The countries that currently have Green Building Rating Systems are Australia, Canada, Germany, India, Japan, New Zealand, South Africa, United Kingdom, and the United States.

The Leadership in Energy and Environmental Design (LEEDINDIA) Green Building Rating System of the Indian Green Building Council promotes a whole-building approach to sustainability by recognising performance in the areas listed below. Builders choose those items that are appropriate for their project:

- Sustainable site selection and development

- Water conservation

- Energy efficiency

- Local resources, material conservation and waste reduction

- Indoor environmental quality. 
Popular features incorporated into green library buildings include:

- Recycled building materials

- Low volatile organic compound (VOC) emitting paints, carpets, and adhesives

- Solar panels

- Day lighting

- Living roofs

- Rainwater harvesting.

Many libraries are incorporating green practices into their everyday operating strategies. These practices may include:

- Recycling paper and cardboard

- Composting organic materials

- Using energy efficient light bulbs

- Using nontoxic cleaning solutions.

- An Indiana (USA) library is built into the side of a hill and has a flat 17250 square-foot living green roof. The soil from the hill helps the library stay cooler in the summer and warmer in the winter, and the runoff water from the roof drains into a rain garden.

- A library in Calgary, Alberta, Canada, incorporates natural and daylight harvesting, exterior sunshades, and on-demand water heating with low-flow plumbing fixtures to reduce the use of water and conserve energy.

- Energy efficiency for a USA library in Ohio will be boosted by a white roof, white concrete in the parking lot, an efficient heatrecovery system, solar shades and a lighting control system. Materials from the demolition of an existing building were recycled, including crushed concrete that went directly into the new building site.

- A library in Santa Monica, CA, USA, includes underground parking, solar electric panels, and a storm water management system used to irrigate the drought resistant landscape. More than $50 \%$ of the building materials contain significant recycled content. The building also uses low-flow restroom toilets and no water urinals. 


\subsection{Building and maintaining library networks}

The library manager must ensure that networks are developed and maintained at the national, regional and local level, to ensure optimum access to ICT and cooperative services. This enables a very wide range of resources to be brought to the customer at a local level. The library manager should also develop effective working partnerships with other organisations in the community, benefiting both the library and its customers and also the partner. Examples include schools, museums and archives, other local government departments and voluntary organisations. Such partnerships confirm the public library's role at the centre of community activity. The library manager should, wherever possible, ensure that the library takes an active and positive role (such as serving as a board member) within the corporate structure of the parent organisation and within the local community.

\subsection{Financial management}

Financial management and financial planning are vitally important to ensure that the library operates efficiently (at optimum performance), economically (at minimum cost), and effectively (at maximum benefit). In order to achieve these aims the library manager should:

- look for ways of improving levels of funding from national, state or local government or from other sources

- prepare 3-5 year business plans based on the library's long term plans, including bids for the required funds

- allocate funds to support activities identified in the library's policy statement and based on the priorities previously determined

- establish partnerships, where appropriate, for co-operative purchasing to maximise the use of available funds

- undertake activity-based costing to determine the cost of activities and programmes and to facilitate future planning

- maintain a policy for the sustainable renewal of plants and equipment

- evaluate and implement automated techniques, wherever appropriate, to improve efficiency and effectiveness

- introduce systems that will ensure that all staff with responsibility for any part of the budget will be fully accountable for the expenditure of funds for which they are responsible

- improve staff productivity and efficiency

- develop strategies for identifying alternative sources of financial support. 


\subsection{Management of library resources}

A major element of a library's budget is expenditure on library materials and services. The library manager should ensure that these funds are spent properly and in accordance with the agreed priorities of the library and that the materials and services are maintained and made available so that they can be of maximum benefit to the library customer.

\subsection{Staff management}

Library staff are a vital element of the library's resources and staff salaries are normally the largest part of the library budget. It is very important that the management of staff should be sensitive, consistent and based on sound principles if staff are to work most effectively and with high levels of motivation and job satisfaction. The following are important elements of staff management:

- An equitable procedure for staff appointments. Job and person specifications should be drawn up prior to a post being advertised. Interviews should be conducted in a way that is fair to all applicants. Appointments should be based solely on professional competence and judgment and suitability for the position and not be prejudiced by any other factors.

- Good communication between staff at all levels. Managers should review internal communication systems regularly to make sure staff are well informed about the policies and procedures of the library service.

- The opportunity for staff to participate in the development of policy and operational procedures. Initiative should be encouraged to make the best use of the skills and experience of staff. By bringing staff into the decision-making process they will feel they 'own' the policies and procedures of the service. The principles of affirmative action may also be adopted.

- Assure opportunities are available for staff training and career development.

\subsection{Planning and development of library systems}

To make the most effective use of resources the public library will require a variety of systems, for example circulation control, financial 
management, internal communications and online access to the Internet. The library manager should ensure that appropriate systems are introduced, making use of specialist staff for their development where necessary. Staff must be given adequate training in the use of such systems, the effectiveness of which must be reviewed regularly.

\subsection{The management of change}

In common with many other organisations public libraries are going through a period of unprecedented and ongoing change as a result of the rapid development of information technology and social and demographic change. This presents tremendous opportunities for the public library, as information provision is one of its primary roles. It also presents challenges to managers and staff to ensure that change can be introduced with the maximum effectiveness and the least stress on staff and the organisation. Library managers must be aware of the issues arising from continuous and fundamental change and establish methods of dealing with them.

\subsubsection{Planning for the future}

Library managers should be aware of developments both within and outside librarianship that are likely to have an impact on service development. They should make time to read and study so that they can anticipate the effect of changes, particularly technological, on the future shape of the service. They should also ensure that policy-makers and other staff are kept informed of future developments.

\subsection{Delegation}

The library manager in charge of the public library service has ultimate responsibility for the service, in conjunction with the governing body. However, all library staff with responsibility for any resources of the library, whether materials, staff or library premises, have a managerial role, and this should be recognised by the library manager and the member of staff concerned. They should be given appropriate managerial training and participate in the policy development of the library whenever possible. Managerial responsibility should be delegated to staff at an appropriate lower level. It should be made clear what responsibilities are being delegated and the reporting mechanism to senior managers. Staff must be given training to enable them to carry out the dele- 
gated responsibilities effectively. A planned system of delegation makes best use of the skills and experience of a wide range of staff and provides opportunities for professional development. It also increases the number of people fully involved in the development and operation of the library service, improves job satisfaction and prepares staff for promotion when opportunities arise.

\subsection{Management tools}

A wide range of management tools can be used in a public library. Their relevance will depend on a number of factors, for example, the cultural context, the size and character of the service, the management style of other departments in the same organisation and available experience and funding. The following are however important tools for public libraries in almost any situation:

- environmental scanning

- community needs analysis

- monitoring and evaluation

- performance measurement.

- The Public Reading Map of Catalonia, Spain is a planning tool for the public library system, identifying requirements for library facilities and subsequent types of services most desirable based upon the population and core demographics. <http://cultura.gencat.cat/biblio/mapa/>

\subsubsection{Environmental scanning}

Marketers often define the internal environment as the "microenvironment." This internal environment must work in partnership with the external environment. The more cognisant the organisation is of this relationship the more proactively it can respond to change. The environment that the library resides within and the materials and services that the library offers, ultimately affect the end users who are the library's customers. The larger environment which is built upon those forces outside the library's control is called the external or "macro environment." These external forces can originate from local, regional, national or international levels. These forces include the state of the economy; the geographical characteristics and infrastructure; competition; legal and political restrictions and issues; technological develop- 
ments; the media; natural resources; and the ever changing social and cultural conditions.

The process of gathering information from these categories aforementioned is in fact the process of "environmental scanning." During this activity, management is constantly identifying strengths and weaknesses in the internal organisation, as well as opportunities and threats from the external environment. Collectively, this is often called the SWOT list: assessing the strengths, weaknesses, opportunities, and threats of an organisation and its environment. This scanning, gathering of critical and relevant data, and the SWOT review, results in the best opportunity to understand what factors facilitate offering optimal products and services that meet the specified needs and desires of the library's customers.

\subsubsection{Community needs analysis}

In order to provide services that meet the needs of the whole community, the public library has to establish the extent of those needs. As needs and expectations will change, this process will need to be repeated at regular intervals, perhaps every five years. A community needs assessment is a process in which the library collects detailed information about the local community and its library and information needs. Planning and policy development are based on the results of this assessment and in this way a match between services and needs can be achieved. In some countries the preparation of a community needs assessment is a legislative requirement of the local authority. The information to be collected will include:

- socio-demographic information about the local community e.g., the age and gender profile, ethnic diversity, educational level

- data about organisations in the community, e.g., educational institutions, health centres, hospitals, penal establishments, voluntary organisations

- information about business and commerce in the locality

- the catchment area of the library, i.e. where library users live in relation to the library

- transport patterns in the community

- information services provided by other agencies in the community.

This is not an exhaustive list and further research would be required to establish what information is needed to form a community needs assessment in each situation. However, the principle of preparing a 
community profile, which will enable the librarian and the governing body to plan service development and promotion on the needs of the community, is an important one whatever the local context. The assessment should be complemented by regular customer surveys to establish what library and information services the public wants, at what level, and how they judge the services they receive. Survey work is a specialist skill and, where resources are available, a more objective result will be gained if the survey is carried out by an external organisation.

\subsubsection{Monitoring and evaluation}

As the library service moves towards its goals, management must be accountable in terms of financial control and the monitoring and evaluation of library activities. Management must continually monitor the performance of the library service to ensure that strategies and operational results are achieving the set objectives. Statistics should be collected over time to allow trends to be identified. Community needs and satisfaction surveys, and performance indicators are valuable tools in monitoring the achievements of the library. Techniques should be developed to measure the quality of the services provided and their impact on the community. All programmes and services should be evaluated on a regular basis to ascertain whether they are:

- achieving the objectives and declared goals of the library

- actually and regularly provided

- meeting the needs of the community

- able to meet changing needs

- in need of improvement, new direction or redefinition

- adequately resourced

- cost effective.

Procedures and processes operating within the library also require constant evaluation and revision to increase efficiency and effectiveness. An outside evaluation and audit is also valuable to assure accountability to the commmunity served and funders.

\subsubsection{Performance indicators}

The availability of reliable performance information is a necessary tool for evaluation and the improvement of efficiency, effectiveness and quality of service (performance measurement). The collection of statistics related to resources, staff, services, circulation, activities etc. will provide 
data for planning, show accountability and assist informed management decision-making. The indicators should be kept up to date.

The following key performance indicators may be used to evaluate and monitor the achievement of the library's objectives.

\section{Usage indicators}

- loans per capita

- total library visits per capita

- membership as a percentage of the population

- loans per item, i.e. turnover resources

- reference and electronic reference enquiries per capita

- loans per opening hour

- number of accesses to electronic services and other non-print materials

- website visits

- comparative data for example, of print and non-print materials

- dowloaded materials, e.g. podcasts

- booking meeting spaces

- registrants vs. active registrants

- number of items placed on hold and percentage of these requests filled from the collection.

\section{Resource indicators}

- total stock per capita

- provision of online public access computers (OPACs) per capita.

\section{Human resource indicators}

- ratio of full time equivalent (FTE) staff to population

- ratio of professional staff to population

- ratio of full time equivalent (FTE) staff to any library usage indicator.

\section{Qualitative indicators}

- customer satisfaction surveys

- enquiries satisfied.

\section{Cost indicators}

- unit costs for functions, services and activities

- $\quad$ staff costs per functions, e.g., books processed, programmes

- total costs per capita, per member, per visitor, per service point etc. 


\section{Comparative indicators}

- bench-mark statistical data against other relevant and comparable library services, internationally, nationally and locally.

In addition to the collection and analysis of input and output service statistics, the unstated needs of potential customers should be established by carrying out market research including the use of focus groups and community surveys.

Where reliable population statistics are not available it becomes more difficult to develop reliable performance indicators. Use can be made of estimated population totals, the comparison of costs with customer and visitor statistics and bench-marking with other libraries with similar characteristics.

\subsubsection{Performance measurement}

Performance measurement has been used in public libraries for some years. Measurements or performance indicators are established to measure the input to libraries, that is the resources devoted to the whole or particular services, and the output: what is achieved as a result of the activity being carried out. For example, the establishment of an enquiry service for customers requires the input of staff, materials, equipment and floor space. The output is the number of enquiries received, the number satisfied, the level of use made of the resources and the use of other services, for example, the reservation service, arising from the original activity. These measures can then be compared each year to see if the effectiveness of the library service is improving.

In the past few years an additional measure has become standard for many libraries, the outcome measure. An outcome measure is a measure of change (or lack of change) in the well-being of a defined customer population. For example, a library may provide homework assistance and tutoring services to school students. The input measure would include the number of books or tutors available, the output would be the hours of tutoring or books circulated and the outcome measure would be the level of improvement of the student's school grades or the student's perception of their increased knowledge.

Computer technology makes performance measurement a simpler task and enables sophisticated models of library use to be established and used in service development. Performance measurement should be a planned process carried out with consistency over a period of time. Further information about library performance indicators can be found in ISO 11620:2008 Information and documentation. Library performance indicators. 
Another way of gaining a useful indication of the success of a library service is to compare key input and output measurements with other public libraries of similar size and characteristics. This is usually known as bench-marking and is a useful adjunct to performance measurements carried out internally.

\section{Resources}

Brophy, P. (2006). Measuring library performance: principles and techniques. London: Facet.

Bryan, C. (2007). Managing facilities for results: Optimizing space for services. Chicago: American Library Association.

Chicago Public Library, Chicago Public Library Foundation, Board Steering Committee, and Boston Consulting Group. (n.d.). Chicago Public Library 2010: A vision for our future. (http://www.chipublib.org/dir_documents/cpl2010.pdf accessed 1/01/2010).

Dowlin, K. (2009). Getting the money: How to succeed in fundraising for public and nonprofit libraries. Westport, CT: Libraries Unlimited.

Elliott, D. S., Holt, G.E., Hayden, S.W., and Holt, L.E. (2007). Measuring your library's value: How to do a cost-benefit analysis for your public library. Chicago: American Library Association.

Herring, M. (2004). Raising funds with friends groups. New York: Neal Schuman.

Hughes, K. M. (2009). The PLA Reader for public library directors and managers. New York: Neal-Schuman.

IFLA. (n.d.) Professional codes of ethics for librarians. (http://www.ifla.org/en/faife/professional-codes-of-ethics-for-librarians accessed 1/01/2010).

Institute of Museum and Library Services (n.d.) Public library data files. (http://harvester.census.gov/imls/data/pls/index.asp accessed 3/15/2010.)

Landau, H. B. (2008). The small public library survival guide. Chicago: American Library Association.

Matthews, J. R. (2008). Scorecard for results: A guide for developing a library balanced scorecard. Westport, CT: Libraries Unlimited.

Nelson, S. S. (2009). Implementing for results: Your strategic plan in action. Chicago: American Library Association.

Rubin, R. J. (2006). Demonstrating for results: Using outcome measurement in your library. Chicago: American Library Association.

United States Environmental Protection Agency. (n.d.). Why build green? (http://www.epa.gov/greenbuilding/pubs/whybuild.htm accessed 1/01/2010). 